\title{
CHARACTERS IN FATOS KONGOLI NOVEL
}

Gjylë TOTAJ, PhD. C.

University of Prishtina “UKSHIN HOTI, Faculty of Filology, gjyla_totaj@hotmail.com

Article history:
$\begin{aligned} & \text { Accepted } 1 \text { May } 2019 \\ & \text { Available online } 30 \text { June } 2019\end{aligned}$
The greater philosopher,Aristotel,dealing with the characters would have said that "due to the fact
that they imitate,they imitate acting people, and these people will of course be good or evil-because
Novel
characters
$\begin{aligned} & \text { Fatos Kongoli } \\ & \text { Kosovo }\end{aligned}$
characters almost always follow these two peculiarities and it is known that the difference of the
novels of our author, Fatos Kongoli, no such traditional line is followed, such distinction is
perceptible in every literature and at any time, and of course, in the novels we are analyzing. Literary
scholar Anton Berisha says that "literary character is an important component element, especially of
epic creations, may they be prose or poetry"(Berisha, 1985). Berisha also adds that "they are known
extremely successful realizations of the characters in the traditional novel, but also in contemporary
and generally modern characters, are noteworthy, but also we do not miss the lyrical characters
through which the subjective world is introduce (Berisha, 1985).

\section{Characters and Narration}

Characters are essential and key points in Fatos Kongoli's novels. They are conveyors, as well as the main pillars of their thematic and conceptual construction. Therefore, they are also rarely classified as novels of the character, because of the size and importance that the characters have within the textual structure.

Fatos Kongoli focuses on the theme of the characters on the chief antagonist around whom the whole story is built up, and most of the episodic situations, motives and characters are auxiliary tools for his realization and portrayal.

Even the secondary characters are quite significant in the narrative of certain novels of this author, like Sonja, Vilma, in the novel "Lost"; Sabit Kurti in the novels "At St. Peter's Gate" and "The Lucky Man"; Valmir D., in the novel "The Ghost" etc. It should be noted that all the major protagonists in the novels of the Congolus are male, except for the Parashqevie, which is the main protagonist of the novel "Bolero in the elder's house“. So we only have a leading female protagonist. In Fatos Kongoli's novels, we see the observer character, who observes more than he does himself. So, a surveillance character. This is the type that appears most frequently among the protagonists of the novels of Fatos Kongoli. As such a character we can get, let's say, Valmir D., Angjelin Kalaja Thesar Lumi, and many other characters, who observe more than they do. They are characters built with the psychic of the fearless who has no courage to take inward action, but just to look forward to what's going on outside.

\section{Identifying Character}

The identifying character of Fatos Kongoli's literature and prose is Thesar Lumi, the protagonist of the "Lost" novel. With this novel and with this character he has become known both for the local reader as well as for the international one. According to the scholar and albanologist, Katarzyna Tachzynska, "with this novel Kongoli has secured himself the top position in the hierarchy of Albanian literature (Tachynska, Prishtinë).

Thesar Lumi has its own point of view and rebukes and confesses too much, which remained an indelible spot in the imagination of a young man. So he confesses to himself and to the others around him. The "Loss" novel from the title itself marks the futility of an individual's life without a specific orientation and purpose. Man in the loss of personal identity. Thesar of the Fatos Kongoli's 
"Lost" novel, represents the profile of a character built on the basis of the absurd pattern whose essence is around the blade of consciousness and the impossible, which are facing each other from the very beginning until the end of the story. He feels lost, as he is aware of the system's corruption, but cannot do anything. Regarding the character of Treasury, the literary scholar Arben Prendi, says that "Lost"is a "novel with a sincere confession, where the protagonist and confessional character positions himself in the present, in the present through a retrospective of the past (Prendi, 2015).

Through the character of Thesar Lumi, we see other characters of the novel, such as Xhodon of Take, Fag, Sonjën, Ladin and so on. Through them is built a very specific and quite distorted world of a reality that can hardly be described as normal. And being such, he takes the trajectory of a reality approaching more absurdly. In his confrontation with Xhodon, who was a functionary and director of the school, Thesar suffered his first defeat. He lost the ideal he had for his father as a possible protector of him and of the truth.

\subsection{Regime and Punishment}

In the "The three of us" novel, we have three main characters, as we can see from his title. So the three characters of this novel are: Miri, Fredi Simaku and Ina. Fredi Simaku is a worker in a factory and is in love with Ina who is an engineer there. Due to bad family biography, Fredi is punished by the communist regime, and in this case, the family of Ina also suffered because he visited them very often during the time they considered their son-in-law. While Miri's character appears more like a child, as the tale in this novel speaks of three age-old protagonists, such as childhood, early youth, and maturity. So the number three in this novel is extremely essential for all aspects of it, in this case for the characters we are discussing.

\subsection{Characters and "Carusel"}

In the novel "Karuseli" of this author we have three main characters, such as Albana Progri, Minella Troja and Agron Gjiknuri. Since we have three narrative tips in this novel, then it is natural to have three main characters, though Albana Progri is more present and representative in terms of narrative situations and thematic motives present in this novel. The first narrative point is that of,Albana Progri, which is also the main character around which the whole story unfolds in this novel of the Konkoli. The second point is that of, Minella Troy, which is the catalyst character of the novel, about which most of the events in this novel are developed. While the third point is that of Agron Gjiknur, styled Edmond Dante, through whom, is linked this work of Kongol. Albana Progri is a young pharmacist, a daughter of an ambassador who has developed a youthful life by being petfriendly by the family and the circle. She's a kind of fragile girl and so the tragedy follows her. She is in love with Minella Troy, while she is loved by Martin and Agron Gjiknuri. Minella Troy is a controversial character and figure. From the beginning of the novel to the end we are presented as a painter and a new professor of art full of love for Albana and his art. While at the end of the novel he appears to us with a feature that completely alters the look of his character. So in him we see a characteristic revelation where the lover comes to us only the careerist, who had all the excitement and all the slanderous courtesy. While Agron Gjiknuri appears to us as a conflicting and libelous character. Many people suffer from lies, including Albana, whom he loved.

\subsection{Subtext from "The Ghost"}

In the novel "The Ghost" of Fatos Kongoli the main character is Festim Gurabardhi. He, besides being the main character of the novel, carries in himself the main messages and subtexts of the novel "The Ghost". It carries all the meaning and is the nucleus of action in this novel. He, besides character, is also a confessor himself, keeping, as the researchers say, "the reader related to him. (Doda, 2006). Through Festim Gurabardhi is best described the figure of a middle and low-ranking regime official, who, though profoundly disagreeing with dictatorship, simply does not do anything except silent disagreement as it turns out to have been the majority of Albanians during the regime of Enver Hoxha. He is not acting, being a character who feels constant fear. He is afraid of the people of the system, even without making any fault, being convinced that dictatorship punishes the individual even when he does nothing when he does neither good nor bad. So we're dealing with a system that penalizes non-nationalists as well. So, it's a character tip that has the dimensions of a passive character that does not turn itself even when it feels he has to do it. So we have a feature anti-hero character that is a sign of the poetics of the modernist novel. A very special character in the novel "The Ghost" is Valmir D, which is one of the most prominent protagonists in the contemporary Albanian prose. Profiling the character Valmir D., who is one of the main actors of the novel "The Ghost" is the most powerful sculpture of a character and a character in our letters. He is the childhood partner of Festim Gurabardh, but also his greatest tormentor. Valmir D., is a human prototype serving the dictatorial system. It is one of the important chain linkages of the system, acting and thinking forever in its hardening. For the most important thing is the system of the man himself, so each individual who posed a danger to the system, for Valmir D.'s mentality, should be punished, regardless of whether he was a friend or a collaborator.

\subsection{Situations and characters in Kongoli novel}


Genc Skampa is the main character of the "Ivory Dragon" novel. $\mathrm{He}$ is one of the most specific characters of Romanesque prose of Fatos Kongoli. He is a full character accomplished in its entirety. To be confessed from his early youth to his old age, when most of his old memories remain of his past memories. So his profile alternates in different parts of this story. The narration starts with Genc Skampën in love and finishes with Genc Skampa in memories.

He during the time of the Chinese Cultural Revolution and the good relations of Enver Hoxha with China of Mao Zedong had been a student at Peking University. There he is introduced to Chinese friends and falls in love with a Chinese girl, Lui Sini. After his compulsory return to Albania, Genc Skampa marries and insists on starting a new life. A life start that never makes him happy, despite being father of two children. He later divorces with his wife and with the already grown children, almost loses contact. He tries to connect with his young girlfriend, Rita, but without success, as he remains hostage to the past. His past is felt most closely during a Paris visit, where he met someone who resembles so much his former Chinese girlfriend Lui Sini. In short, these are the voices of a character like Genc Skampa of our novel.

In the novel "Damokleut's Dream" the main character is Ergysi. $\mathrm{He}$ is one of the most prominent characters of Romanesque prose of Fatos Congolese. In his actions, we see a combination of what we can call a realistic character and what we can call it a fantasy character. So a no typical kind of Kongoli novel, when we consider that most of his characters are in the midst of realistic portraying and portraying as absurd beings, which goes far beyond portraying the characters of modernist prose. Ergysi is a persuaded character that a supernatural hand, a secret hand, guides the destiny of destiny, drives human life and its development. So a character covered with fatalism. This sensation makes you walk in situations of psychological delusions. In such a state he faces Damokleu, a mythological figure recognized by antiquity.

Kristi Tarapi of the novel "The Skin of the Dog" is one of the most distinctive characters not only of the prose of Kongol, but of all contemporary Albanian literature. $\mathrm{He}$ is the chief protagonist of the novel "Dog Skin". Around him behave all the actions, all motives and ideas that may arise from reading and interpreting the text. Kristi Tarapi is a character that feels lonely, like many characters of his creator's novels as a character. Apart from being alone, he has an indescribable sense of selfdepreciation and a fearful fear of what might happen to him and his close people. An absurd character that apart from individual existence is not that there is any interest in other things. Like most of the characters of Kongoli, Kristi is not part of any great social and political cause, nor does he or she bare such things. He is also unfulfilled in the emotional and erotic plan. He is the illusionist who only tends to do this, but is not making great concrete efforts.

In this aspect, and in that of the illusionist dimension of the character, Christi Tarapi differs from other characters of Kongol who do not have this dimension. In the novel "At St. Peter's Gate" we have four very specific characters and each is the bearer of the narrative in its own way. We are dealing with a novel by the rarest of Kongol, where we do not have a leading character as a narration carrier. So the four characters of this novel are: Plator Guri, Ardiana Gjini, Sabit Kurti and Erald Perjaku. Plator Guri is a university professor of history and married to Ardiana Gjini, an important woman in the cultural districts of the capital of Albania, Tirana. It's a tragic, as grotesque character. It is the victim of an accidental attack of a group who had thought of killing someone else but he accidentally he had been there and the bullet had hit him.

Ardiana Gjini is a well-known writer of Tirana and the wife of the historian Plator Guri. She is a character that is more engraved through the realistic prose model. In one way or another, it is a grotesque victim of reality created during the years of democratic transition in Albania. She suffers the fact that her husband is in a coma, in a state of shyness between life and death, as well as the insults that the media are doing just about the case of her husband's serious injury. Sabit Kurti is a police investigator who has been searching for criminal groups that function in the neighborhoods of the Albanian capital. His investigation did not succeed because of the links of these groups with different segments of the state. His investigation gives, as we have said, the novel "At St. Peter's Gate" an aspect of the police narrative that is a narrative way lacking in Albanian artistic prose. This character is also present in the novel "Lucky Man" by the same author. While Erald Perjakut is a young boy from northern Albania, from peripheral areas of the country, living in a peripheral suburb of the capital, which in the confession is called by the capitals as "Chechnya". Such a young man with significant material and cultural shortages, poor in many dimensions, turns into a "devoted soldier" of the criminal group led by the owner of the "Lura" complex.

In the novel "Life in a Racket Box" as the main character and carrier of ideas and confession we have Bledi Terziu who is a journalist in profession. His life and routine changes due to a coincidence. Such a thing causes absurd situations in this novel by Fatos Kongoli. Bledi Terziu, in completely random circumstances, turns into a criminal, without his will. In his apartment comes randomly a gipsy girl and he invites her to make sex. So this gipsy girl accidentally dies in the bathroom of the 
Bled apartment. He falls into doubt whether he should call the police about the tragic case in his apartment, or throw the corpse of the new gipsy girl into the suburbs of the city. Being frightened of what might have happened, if he admitted that such a thing had happened in his apartment, he chooses the second option. She throws the girl's corpse in a remote area on the outside part of the city. So the journalist Bledi Terziu inadvertently makes a crime, not because the girl dies in his apartment, but because he had thrown her corpse as a common criminal. An accidental death that would change the course of life to our main character.

In the novel "Bolero in the elders house" as a protagonist and confessor is Parashqevia, a nurse in profession, who speaks to us of her past and present, her problems and special moments of life. Confessing from a woman's point of view, we can emphasize that we are dealing with a narrative quality and deep psychological recognition by the author, a dimension that completes Kongol as a prose. The character of Parashqevi, is one of the most powerful and most complete characters of this artist's prose. It is one of the few characters of Kongol that tries to change something, do something different from others or, better say she has a revolt of her own. She takes care of two lonely elders, since she is a nurse in profession and is constantly close to them, tracking the fate of the two neglected beings that their relatives already consider to be excessive. Parashqevia has a problem with itself. There is a lack of self-confidence and self-realization.

She feels ugly and there is a nervousness that goes so far as to hate herself. She also has a feeling for the same sex. He loves Hannah and feels great pain when she dies in the civil conflict that occurred in Albania in 1997. Parashqevia suffered a traumatic shock during these disrupted riots this year. She is sexually raped by a group of boys led by Anne's brother.

In the novel "Gjemia e mbytur", the main character is Glauk Fusha, a forty-two year old who returns to Albania after a time of migration. He is looking for his identity and truth about his family. In his quest to know himself, his family and his circle, and to find out the truth, Glauk becomes a tremendous terrorist of the people of the former communist Albanian regime. He puts the fear of the former regime servants, especially those who were responsible for killing his father, Berti Fusha. A very special and extremely significant personage for this novel by Fatos Kongoli is the character of Dhimo Shkurat who is an elder about seventy. He had been one of the most important people in the hierarchy of the communist bloody regime. Dhimo Shkurra is in a way the directly causes the Glauk Fushë family's tragedy during the time of communism.
In the novel "Si-do-re-la" the main character is Ardi, a young man around the age of thirty who has the profile of a memorial character that continues to be mindful of a past love, a love of early youth that is also really his first love. It is in constant memories of Dorna, which he always remembers, no matter how long years pass and no matter he meets many other women. He meets again after many years with Doras that some called Ela, and some to ridicule him and call him Sida. So by the unification of these three names comes the acronym "Si-do-re-la" that for Ardin is a vital motive and element that makes him live with a beautiful memory he wanted to return over and over again.

In the novel "Lucky Man" we have two main characters, such as Sabit Kurti and Gentian Engjëll. Due to the fact that in this novel there are two thematic lines, then the addition of two characters is a natural thing. The first character, Sabit Kurti, is linked to the line of the first thematic motif that characterizes this novel of Kongoli. Sabit Kurti is a special character of this author. He is also present in other novels of this author, especially in the novel "At Saint Peter's Gate". In this novel comes the same features as in the previous one. Sabit Kurti is invited to investigate a sensible case, to uncover a crime that had occurred in a hotel built at the foot of the Albanian coast. At the hotel with no ordinary name "Elsinor" there has been a crime and the task of the old investigator is to uncover the truth. Gentian Engjelli is the key character around which the second thematic aspect of the novel "Lucky Man" arises. He is in the midst of two love: real and illusive and virtual. His real love is called Cleopatra, a beautiful blonde, while his illusive love is called Vega, a girl with big black eyes. Two parallel love of the main character, one real, the other virtual, develop into a dimension as absurd as grotesque.

"Illusion in the drawer" is an autobiographical novel, so naturally the character is the author himself. So we do not find it appropriate to deal with the same logic as the characters of fiction romances, even though they have autobiographical signs, but we have preferred to read them as fiction, since for such a biographical and autobiographical reading we need the help of the psychoanalytic method of literature study. Also, in the stories of Kongol, we have not encountered any character that is representative and equally valuable in terms of stylistic and conceptual, as is the character of a series of novels of this author. Based on this, we have not seen the story of characters in the same line with the characters of Fatos Kongoli's novels that are among the most interesting in today's Albanian novel.

\section{Conclusion}

There are many characters in Fatos Kongoli prose which are related to the Albanian reality and their past life connected with many of before, during and after communist situations. The whole 
construction of Kongoli novels are numerous situations lived by each character. It should be noted that the variety of characters' actions in the novel of Kongoli and many other credible facts are the human situations and actions artistically presented by the author in his novels.

Kongol has written a lot of novels, so it is not enough to talk about each of them in just an article, so it remains for another occasion to present in more details the other situations in his novels.

\section{References}

1. KONGOLI, Fatos, "Bolero in elders house ", novel, Toena Publishing House, Tiranë, 2009.

2. KONGOLI, Fatos, "Ivory Dragon",novel, Toena Publishing house, Tiranë, 2009.

3. KONGOLI, Fatos, “Damokleu Dream”, novel,Toena Publishing House, Tiranë, 2004.

4. KONGOLI, Fatos, "Gjemia e mbytur", novel, Toena, Tiranë, 2015.

5. KONGOLI, Fatos, "The Lost", novel, Faik Konica Publishing House, Prishtinë, 2000.

6. KONGOLI, Fatos, "Ilusions in the drawer",Toena Publishing House, Tiranë, 2010.

7. KONGOLI, Fatos, "Life in a racket box", novel, Toena Publishing Tiranë, 2009.

8. KONGOLI, Fatos, "Carusel”, novel,Toena Publishing Tiranë, 2007.

9. KONGOLI, Fatos, "The Ghost", novel, Toena Publishing, Tiranë, 2007.

10. KONGOLI, Fatos, "Dog"s leather", novel Toena Publishing, Tiranë, 2006.

11. KONGOLI, Fatos, "The three of us", novel, Toena Publishing, Tiranë, 2006.

12. KONGOLI, Fatos. "The lucky man", novel, Toena Publishing, Tiranë, 2015.

13. KONGOLI, Fatos, "Si-do-re-la", novel,Toena Publishing, Tiranë, 2011.
14. KONGOLI, Fatos: "To Saint Peter"s gate ", novel,Toena publishing, Tiranë, 2006.

15. ELSIE, Robert: "History of Albanian Literature", Dukagjini, Pejë, 1996

16. HAMITI, Sabri: "Albanisma”, Akademy of Science and Arts of Kosovo; Special Publishing CIII; Section of Linguistics and Literature; Book 42, Prishtinë, 2009

17. OLLURI, Adil: "Face of tirany: narration of dictatiorship in the contemporary albanian novel",Albanologic Institute of Prishtina, Prishtinë, 2017.

18. QOSJA, Rexhep: "New albanological notions ", Albanologic Institute, Prishtinë, 1983.

19. TODD, Allan: "The europian dictatorships: Hiteler, Stalin, Mussolini”, Cambridge University Press, Cambridge-UK, 2002.

20. VINCA, Agim: “Albanian alternative literature",third edition,Albanologic Institute, Prishtinë, 2009.

21. VINCA, Agim, "Lost-the novel that signed the success of an authori", literary magazine“Jeta e re", no 1, year XLVI, Prishtinë, 2015

22. XHAFERRI, Hamit, Novel "Dog"s skin" of Fatos Kongolit, International Seminar of Albanian Language,Literature XXVIII nr. 28/2, Prishtinë, 2009.

23. MEHMETAJ, Albana, "Literature of absurd- Kamy dhe Kongoli”, Jeta e re,literary magazine, Prishtinë, nr. 3, 2010.

24. PASHO, Severine, "Prose of Kongoli- labirinth of human pain”, literary magazine Mehr Licht, Tiranë, 2007.

25. PRENDI, Arben, "Albanian contemporary literature": Combination of poetics and decodation of metaphysic realities in contemporary albanian literature", Fiorentina, Shkodër, 2015. 